\title{
Modulation of the Cold-Activated Channel TRPM8 by Lysophospholipids and Polyunsaturated Fatty Acids
}

\author{
David A. Andersson, ${ }^{1,2}$ Mark Nash, ${ }^{2,3}$ and Stuart Bevan ${ }^{1,2}$ \\ ${ }^{1}$ Wolfson Centre for Age-Related Diseases, King's College London, London SE1 1UL, United Kingdom, ${ }^{2}$ Novartis Institute for Biomedical Sciences, London \\ WC1E 6BS, United Kingdom, and ${ }^{3}$ Novartis Institute for Biomedical Sciences, Horsham, West Sussex RH12 5AB, United Kingdom
}

We investigated the role of phospholipase $\mathrm{A}_{2}\left(\mathrm{PLA}_{2}\right)$ and the effects of PLA 2 products (polyunsaturated fatty acids and lysophospholipids) on the cold-sensitive channel transient receptor potential (melastatin)-8 (TRPM8), heterologously expressed in Chinese hamster ovary cells. TRPM8 responses to cold and the agonist icilin were abolished by inhibitors of the calcium-independent (iPLA 2 ) form of the enzyme, whereas responses to menthol were less sensitive to $\mathrm{PLA}_{2}$ inhibition. Inhibition of $\mathrm{PLA}_{2}$ similarly abolished the cold responses of the majority of cold-sensitive dorsal root ganglion neurons. The products of PLA 2 had opposing effects on TRPM8. Lysophospholipids (LPLs) (lysophosphatidylcholine, lysophosphatidylinositol, and lysophosphatidylserine) altered the thermal sensitivity of TRPM8, raising the temperature threshold toward normal body temperature. Polyunsaturated fatty acids (PUFAs), such as arachidonic acid, inhibited the activation of TRPM8 by cold, icilin, and menthol. The relative potencies of lysophospholipids and PUFAs are such that lysophosphatidylcholine is able to modulate TRPM8 in the presence of an equimolar concentration of arachidonic acid. Positive modulation by LPLs provides a potential physiological mechanism for sensitizing and activating TRPM8 in the absence of temperature variations.

Key words: TRPM8; phospholipase A2; lysophospholipid; arachidonic acid; menthol; icilin

\section{Introduction}

Members of the transient receptor potential (TRP) family of ion channels function as sensors of the physical and chemical environment (Clapham, 2003). Light, chemicals, touch, temperature, and osmolarity are examples of stimuli that can activate different TRP channels. Several TRP channels are thermosensitive and together they confer the ability to sense temperature throughout the range from noxious cold to noxious heat (Jordt et al., 2003; Patapoutian et al., 2003). Thus, TRPV1 is activated near the threshold for noxious heat pain, whereas TRPV2 is stimulated by even higher temperatures (Caterina et al., 1997, 1999). TRPV3 and TRPV4 both sense "warm" temperatures around and below body temperature (Guler et al., 2002; Peier et al., 2002b; Smith et al., 2002; Xu et al., 2002). Transient receptor potential (melastatin)-8 (TRPM8) is activated by cold with a threshold temperature of $\sim 25^{\circ} \mathrm{C}$ (McKemy et al., 2002; Peier et al., 2002a; Story et al., 2003).

TRPM8 is expressed in a subpopulation of small coldsensitive dorsal root ganglion (DRG) neurons consistent with its proposed function as a thermosensor. TRPM8 is also expressed in sensory nerves innervating deeper tissues that, under normal circumstances, never experience the low temperatures $\left(<25^{\circ} \mathrm{C}\right)$ necessary to activate the channel. In these tissues, it is likely that

Received Nov. 7, 2006; revised Feb. 16, 2007; accepted Feb. 19, 2007

This work was supported in part by a grant from the Medical Research Council. We thank Isabelle Garnier for her contribution to the 96-well plate assays.

Correspondence should be addressed to David Andersson, Wolfson Centre for Age-Related Diseases, Guy's Campus, King's College London, London SE1 1UL, UK. E-mail: david.andersson@kcl.ac.uk.

DOI:10.1523/JNEUROSCI.4846-06.2007

Copyright $\odot 2007$ Society for Neuroscience $\quad$ 0270-6474/07/273347-09\$15.00/0
TRPM8 is activated or modulated by endogenous agonists or mechanisms other than temperature.

The activities of many TRP channels are regulated by lipids. $\mathrm{PIP}_{2}$, diacylglycerol, and polyunsaturated fatty acids have been shown to activate or inhibit various TRP channels directly (Runnels et al., 2002; Clapham, 2003; Hardie, 2003; Liu and Liman, 2003; Liu and Qin, 2005; Rohacs et al., 2005). Polyunsaturated fatty acids (PUFAs) and arachidonic acid metabolites constitute a distinct group of lipids that can act as endogenous agonists at some TRP channels. TRPV3 is activated by unsaturated fatty acids, TRPV1 by anandamide and lipoxygenase products, and TRPV4 by epoxyeicosatrienoic acids produced by cytochrome P450 mono-oxygenases (Zygmunt et al., 1999; Hwang et al., 2000; Watanabe et al., 2003; Hu et al., 2006).

In this study, we have examined the role of phospholipase $A_{2}$ $\left(\mathrm{PLA}_{2}\right)$ in the activation of TRPM8. All PLA 2 enzymes hydrolyze the sn-2 ester of glycerophospholipids to release a free polyunsaturated fatty acid (PUFA) and a lysophospholipid (LPL). Two main groups of intracellular $\mathrm{PLA}_{2}$ enzymes exist, cytosolic $\mathrm{PLA}_{2}$ $\left(\mathrm{CPLA}_{2}\right)$ and calcium-insensitive PLA $2\left(\mathrm{PLA}_{2}\right)$, also called group IV and group VI PLA 2 , respectively. Although $\mathrm{CPLA}_{2}$ is selective for phospholipids with arachidonic acid in the sn-2 position, this is not the case for $\mathrm{iPLA}_{2}$, which releases other fatty acids as well (Balsinde and Balboa, 2005). Here we report the discovery of a key role for $\mathrm{iPLA}_{2}$ in the regulation of TRPM8 and show that lysophospholipids, produced by $\mathrm{PLA}_{2}$ activity, positively modulate TRPM8 and can act as endogenous agonists to activate the channel at normal physiological temperatures. In contrast, PUFAs such as arachidonic, eicosapentaenoic, and docosahexaenoic acid inhibit TRPM8. Although the two groups of $\mathrm{PLA}_{2}$ products exert opposing modulatory effects on TRPM8, the net bal- 
ance of equimolar concentrations of the $\mathrm{PLA}_{2}$ products favors TRPM8 activation. These findings introduce lysophospholipids as novel modulators of thermosensitive TRP channel activity.

\section{Materials and Methods}

Cell culture. Chinese hamster ovary $(\mathrm{CHO})$ cells expressing mouse TRPM8 (Peier et al., 2002a) were grown in MEM $\alpha$ medium without ribonucleosides and deoxyribonucleosides, supplemented with penicillin (100 U/ml), streptomycin $(100 \mu \mathrm{g} / \mathrm{ml})$, L-glutamine (2 $\mathrm{mm})$, FCS $(10 \%)$, and hygromycin B (200 $\mu \mathrm{g} / \mathrm{ml})$.

$D R G$ cultures. DRG neurons were prepared from adult $(\sim 200 \mathrm{~g})$ male or female Wistar rats as described previously (Bevan and Winter, 1995). Rats were asphyxiated with $\mathrm{CO}_{2}$ as approved by the United Kingdom Home Office, and spinal ganglia were removed aseptically from all levels of the spinal cord. Ganglia were incubated in $0.125 \%$ collagenase type IV (Worthington Biochemical, Lakewood, NJ) for $3 \mathrm{~h}$ in DMEM (Invitrogen, Paisley, UK) with $2 \mathrm{~mm}$ L-glutamine at $37^{\circ} \mathrm{C}$ in a humidified incubator gassed with $5 \% \mathrm{CO}_{2}$ in air. Neurons were dissociated mechanically by trituration with a flamepolished Pasteur pipette. The DRG neurons were centrifuged through 2 $\mathrm{ml}$ of $15 \%$ bovine albumin in DMEM media, and the pellet was resuspended in DMEM with 10\% fetal bovine serum (Invitrogen), $2 \mathrm{~mm}$ L-glutamine, $10 \mu \mathrm{g} / \mathrm{ml}$ penicillin and streptomycin, and $50 \mathrm{ng} / \mathrm{ml} \mathrm{NGF}$ (Promega, Madison, WI). The neurons were plated onto sterile $13 \mathrm{~mm}$ glass coverslips previously coated with $10 \mu \mathrm{g} / \mathrm{ml}$ poly-D-lysine and 5 $\mu \mathrm{g} / \mathrm{ml}$ laminin and maintained at $37^{\circ} \mathrm{C}$ in a humidified incubator gassed with $5 \% \mathrm{CO}_{2}$.

Imaging of intracellular calcium levels. CHO cells and DRG neurons were grown on glass coverslips covered with poly-D-lysine and loaded with $2 \mu \mathrm{M}$ fura- $2 \mathrm{AM}$ (Invitrogen, Leiden, The Netherlands) for $\sim 1 \mathrm{~h}$ in the presence of $1 \mathrm{~mm}$ probenecid and $0.01 \%$ pluronic $\mathrm{F}-127$ at $37^{\circ} \mathrm{C}$ before the experiments. The dye loading and the subsequent experiments were performed in an assay buffer containing the following (in mM): 140 $\mathrm{NaCl}, 5 \mathrm{KCl}, 10$ glucose, $10 \mathrm{HEPES}, 2 \mathrm{CaCl}_{2}$, and $1 \mathrm{MgCl}_{2}$, buffered to $\mathrm{pH}$ $7.4(\mathrm{NaOH})$. Compounds were applied to cells by local microperfusion of solution through a fine tube placed very close to the cells being studied. The temperature of the perfusion buffer was controlled by a regulated Peltier device (Marlow Industries, Dallas, TX) and monitored by a thermocouple positioned in the tip of the perfusion tube. Images of a group of cells were captured every $2 \mathrm{~s}$ at 340 and $380 \mathrm{~nm}$ excitation wavelengths with emission measured at $520 \mathrm{~nm}$ with a microscope-based imaging system (PTI, Birmingham, NJ). Analyses of emission intensity ratios at $340 / 380 \mathrm{~nm}$ excitation ( $R$, in individual cells) were performed with the ImageMaster suite of software.

Neurons in DRG cultures were identified at the end of the experiment by stimulation with an assay buffer supplemented with $50 \mathrm{~mm} \mathrm{KCl}$. The resultant depolarization opened voltage-gated calcium channels in the neurons and evoked a calcium influx that was detected by a change in the $340 / 380$ emission ratio.

Electrophysiology. Cells expressing TRPM8 were grown on glass coverslips covered with poly-D-lysine and studied by whole-cell voltage-clamp recordings using an Axopatch 200A amplifier and pClamp 8.0 software (Molecular Devices, Union City, CA). Experiments were performed at a holding potential of $-60 \mathrm{mV}$, unless stated otherwise. Borosilicate glass pipettes (2-5 M $\Omega$ ) were filled with the following (in $\mathrm{mM}$ ): $140 \mathrm{KCl}, 0.05$ $\mathrm{CaCl}_{2}, 1 \mathrm{MgATP}, 0.1 \mathrm{EGTA}$, and 10 HEPES. The external assay buffer was the same as described above for imaging of intracellular $\mathrm{Ca}^{2+}$. The cells were superfused locally through a thin tube positioned very close to the cells.

Ninety-six-well plate-based intracellular calcium assays. In some experiments, changes in intracellular calcium were determined in TRPM8 expressing CHO cells grown in 96-well black-walled plates (Costar, Cam-
B
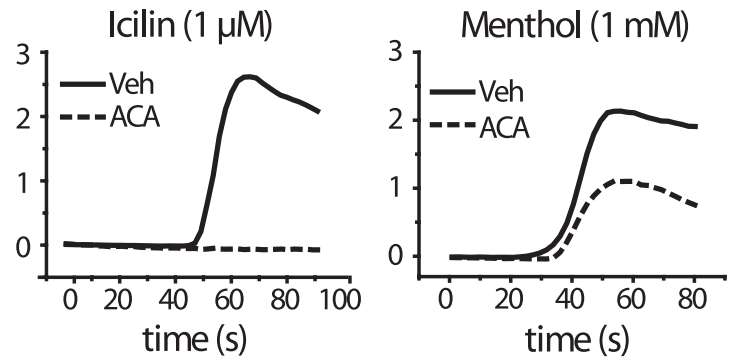
Table 2. PLA 2 inhibitors reduce the proportion of cold-sensitive cultured DRG neurons

\begin{tabular}{llll}
\hline & \multicolumn{1}{c}{ Cold } & Menthol & Icilin \\
\cline { 2 - 3 } Control & [threshold $\left.\left({ }^{\circ} \mathrm{C}\right)\right]$ & 71 of $1039(6.8 \%)$ & 57 of $634(9.0 \%)$ \\
ACA $10 \mu \mathrm{M}$ & $\left(25.7 \pm 1.0^{\circ} \mathrm{C}\right)$ & & \\
BEL $25 \mu \mathrm{M}, 45 \mathrm{~min}$ & 17 of $448^{* * *}(3.8 \%)$ & 24 of $565^{*}(4.2 \%)$ & 5 of $365^{* * *}(1.4 \%)$ \\
& $\left(21.5 \pm 2.2^{\circ} \mathrm{C}\right)$ & & 2 of $374^{* * *}(0.5 \%)$ \\
\hline
\end{tabular}

${ }^{*} p<0.05,{ }^{* *} p<0.01,{ }^{* * *} p<0.001$, compared with control

A

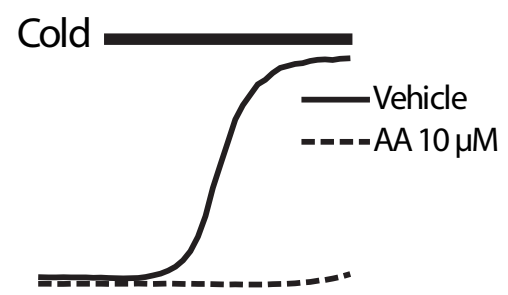

C
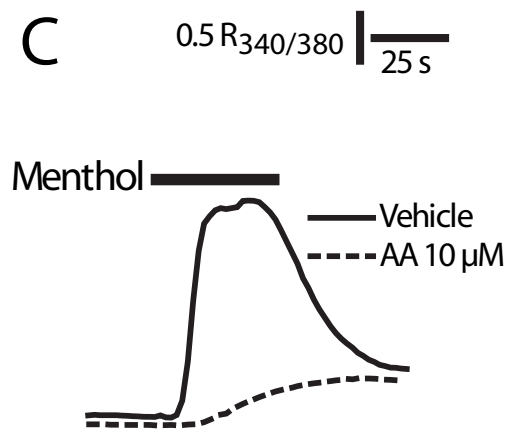

\section{B}
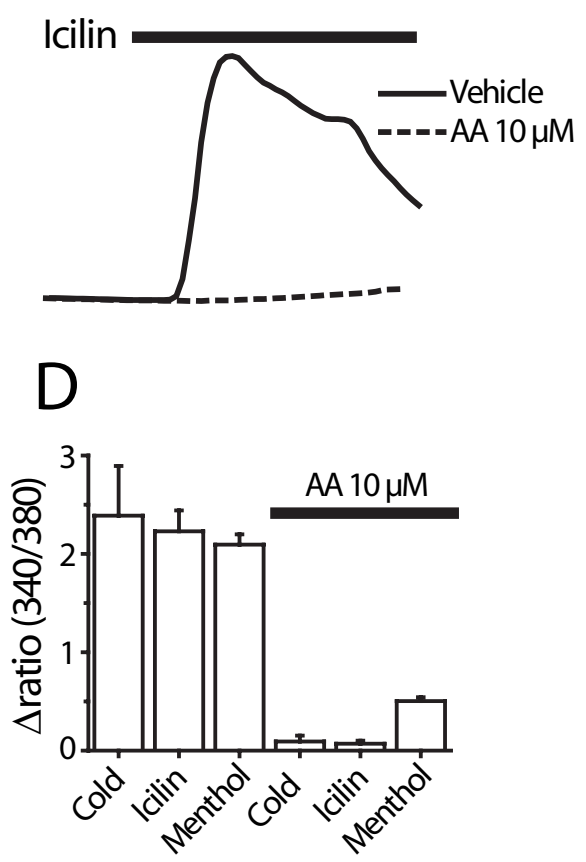

Figure 3. Arachidonic acid inhibits TRPM8. $\boldsymbol{A}, \boldsymbol{B}$, Arachidonic acid (AA) $(10 \mu \mathrm{m})$ almost completely inhibited $\left[\mathrm{Ca}^{2+}\right]_{\mathrm{i}}$ responses induced by a cold ramp from $37^{\circ} \mathrm{C}$ to $12^{\circ} \mathrm{C}(\boldsymbol{A}), 100 \mathrm{~nm}$ icilin $(\boldsymbol{B})$, and $100 \mu \mathrm{m}$ menthol $(\boldsymbol{C})$. Each trace is the average response from a group of cells $(n=25-50)$ monitored individually. The average peak response amplitude of experiments like those in $\boldsymbol{A}-\boldsymbol{C}$ is shown in $\boldsymbol{D}(n=3-4)$.

raynoic acid (ETYA), and E-6-(bromomethylene)tetrahydro-3-(1-naphthalenyl)-2 $H$-pyran-2-one (BEL) were obtained from Calbiochem (La Jolla, CA). Icilin was obtained from Tocris Bioscience (Ellisville, MO) and arachidonic acid, lysophospholipids, fatty acids, and all other reagents were purchased from Sigma (St. Louis, MO).

Calculation and statistics. Data are presented as means \pm SEM for the number of experiments indicated $(n)$. Curve fitting was performed in Origin 7 (OriginLab, Northampton, MA). Statistical significance was calculated using an unpaired $t$ test or ANOVA, followed by Bonferroni's post hoc test.

\section{Results}

\section{Inhibition of $\mathrm{PLA}_{2}$ prevents activation of TRPM8}

We used fura-2 to monitor the effect of $\mathrm{PLA}_{2}$ inhibition on $\left[\mathrm{Ca}^{2+}\right]_{\mathrm{i}}$ responses induced by cold, icilin, and menthol in $\mathrm{CHO}$ cells expressing TRPM8. The PLA 2 inhibitors were applied by superfusion for $2 \mathrm{~min}$ before the cells were challenged with cold, menthol, or icilin.

ACA, a cell-permeable, nonselective $\mathrm{PLA}_{2}$ inhibitor, completely inhibited responses to stimulation with icilin $(1 \mu \mathrm{M})$ or cold (cold ramp to $13^{\circ} \mathrm{C}$ ) and reduced the amplitude of $\left[\mathrm{Ca}^{2+}\right]_{\mathrm{i}}$ responses evoked by $1 \mathrm{~mm}$ menthol (Fig. 1). ACA does not distinguish between different $\mathrm{PLA}_{2}$ isoforms. To identify the enzyme targeted by ACA in $\mathrm{CHO}$ cells, we examined the effects of $\mathrm{PLA}_{2}$ inhibitors selective for $\mathrm{iPLA}_{2}$ and $\mathrm{CPLA}_{2}$ on TRPM8 activity. A potent and selective cellpermeable cPLA 2 inhibitor, cPI (100 nM) (Seno et al., 2000), had no effect on the responses to menthol, icilin, or cold (Table 1). In contrast, 45 min of incubation with a selective irreversible and cellpermeable iPLA $\mathrm{A}_{2}$ inhibitor, BEL $(20 \mu \mathrm{M})$, almost completely inhibited the $\left[\mathrm{Ca}^{2+}\right]_{\mathrm{i}}$ responses evoked by cold and icilin but only produced a small inhibition of the response to menthol (Table 1). ETYA, a general inhibitor of arachidonic acid metabolism, and the lipoxygenase inhibitor nordihydroguaiaretic acid (NDGA), are two compounds that also inhibit $\mathrm{PLA}_{2}$ (Lanni and Becker, 1985). Both compounds had the same profile as BEL and ACA. ETYA $(10 \mu \mathrm{M})$ and NDGA $(20 \mu \mathrm{M})$ effectively inhibited the responses to icilin and cold but had only a small effect on the response to menthol (Table 1). Because TRPM8 was sensitive to BEL and nonselective inhibitors of $\mathrm{PLA}_{2}$, but not to the $\mathrm{CPLA}_{2}$ selective inhibitor $\mathrm{cPI}$, our results strongly implicate $\mathrm{PLA}_{2}$ in the maintenance and regulation of TRPM8 activity.

Menthol-induced $\left[\mathrm{Ca}^{2+}\right]_{i}$ responses showed a different sensitivity to $\mathrm{PLA}_{2}$ inhibition than those evoked by icilin and cold (Table 1). Conditions that completely inhibited responses to cold and icilin (ACA, $10 \mu \mathrm{M}$; BEL, $20 \mu \mathrm{M}$ for $45 \mathrm{~min}$ ) only partially reduced the responses to menthol. This parallels previous findings that responses to menthol are less sensitive to the intracellular $\mathrm{Ca}^{2+}$ concentration and $\mathrm{pH}_{\mathrm{i}}$ than those elicited by cold and icilin (Andersson et al., 2004; Chuang et al., 2004). To characterize the abilities of $\mathrm{PLA}_{2}$ inhibitors to inhibit the responses evoked by menthol and icilin in more detail, we constructed inhibition-response curves studying the effects of different concentrations of ACA and BEL on TRPM8 responses evoked by fixed concentrations of agonist (Fig. 2). In these experiments, we used concentrations of icilin (40 nM) and menthol $(40 \mu \mathrm{M})$ that elicit submaximal responses of similar amplitude ( $\sim \mathrm{EC}_{80}$ concentrations). ACA and BEL completely inhibited responses to icilin $\left(\mathrm{IC}_{50}\right.$ values of $0.46 \pm 0.1$ and $8.6 \pm 2 \mu \mathrm{M}$, respectively), whereas much higher concentrations of these inhibitors were required to inhibit the $\left[\mathrm{Ca}^{2+}\right]_{\mathrm{i}}$ responses to menthol $\left(\mathrm{IC}_{50}\right.$ values of $6.9 \pm 3$ and $30 \pm 4 \mu \mathrm{M}$ with $\mathrm{ACA}$ and BEL).

Although BEL is regularly used to determine the involvement of $\mathrm{iPLA}_{2}$, it is also a well documented inhibitor of phosphatidic acid phosphohydrolase 1 (PAP-1). We addressed the possibility that the effect of BEL was attributable to PAP-1 inhibition by using propranolol, which at high concentrations is an inhibitor of PAP-1 (Fuentes et al., 2003). At a relevant 
high concentration $(250 \mu \mathrm{M})$, propranolol failed to inhibit $\left[\mathrm{Ca}^{2+}\right]_{\mathrm{i}}$ responses to cold or icilin, ruling out the involvement of PAP-1 (data not shown).

Effects of PLA 2 inhibition on native TRPM8 in DRG neurons TRPM8 is expressed in sensory neurons in trigeminal and dorsal root ganglia. In good agreement with previous studies (Peier et al., 2002a), we found that $6.8 \%$ of DRG neurons in culture were sensitive to stimulation with menthol and $9 \%$ to icilin (Table 2). Cold stimulated a slightly larger cell population (11.6\%) (Table 2). Two distinct populations of cold-sensitive DRG neurons have been described based on their sensitivity or insensitivity to menthol and differences in threshold temperatures (Story et al., 2003; Babes et al., 2004). Story et al. (2003) found that mentholsensitive neurons had a temperature threshold of $\sim 23^{\circ} \mathrm{C}$, whereas the threshold for the menthol-insensitive neurons was lower, $\sim 15^{\circ} \mathrm{C}$. A smaller difference in temperature threshold for menthol-sensitive $\left(24.9^{\circ} \mathrm{C}\right)$ and menthol-insensitive $\left(22.9^{\circ} \mathrm{C}\right)$ neurons was noted by Babes et al. (2004). Nevertheless, both studies showed that TRPM8 expression was associated with higher temperature thresholds. We noted that treatment with either ACA $(10 \mu \mathrm{M})$ or BEL $(25 \mu \mathrm{M})$ reduced the population of cold-sensitive neurons to $<4 \%$. ACA and BEL also significantly reduced the number of menthol-sensitive neurons and inhibited the effect of icilin almost completely (Table 2). The percentage of cold-sensitive neurons that were resistant to inhibition of $\mathrm{PLA}_{2}$ was the same as the percentage of menthol-insensitive, coldsensitive neurons. Interestingly, the temperature threshold for cold-sensitive DRG neurons after $\mathrm{PLA}_{2}$ inhibition was $4-7^{\circ} \mathrm{C}$ lower than in the overall population (Table 2). Thus, our data are consistent with the conclusion that cold and icilin activation of TRPM8 in DRG neurons, as in CHO cells, was abolished by iPLA 2 inhibition and that the small remaining population of (nonTRPM8) cold-sensitive DRG neurons require lower temperatures for activation. In addition, menthol responses in DRG neurons were more resistant to $\mathrm{PLA}_{2}$ inhibition than those to cold and icilin, similar to our results in $\mathrm{CHO}$ cells.

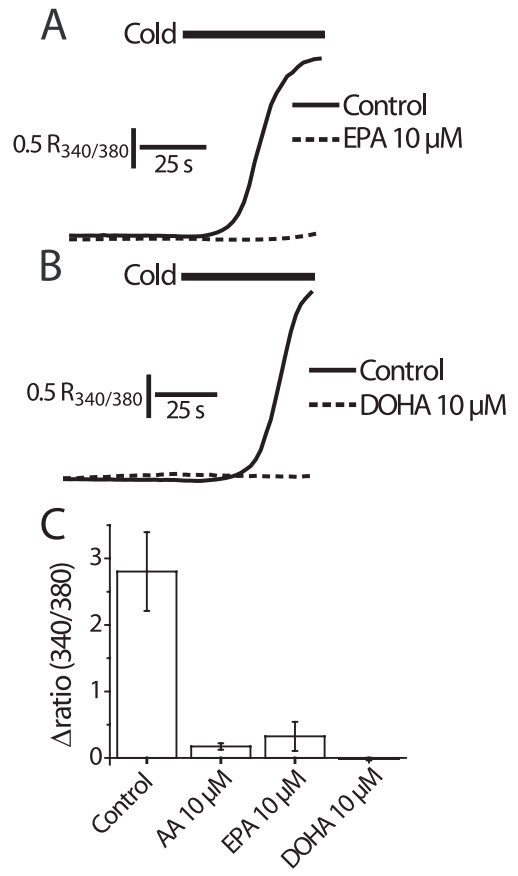

Figure 4. TRPM8 is sensitive to polyunsaturated fatty acids. $\boldsymbol{A}, \boldsymbol{B}$, Eicosapentaenoic acid $(E P A)(\boldsymbol{A})$ and docosahexaenoic acid (DOHA) $(\boldsymbol{B})$ prevented $\left[\mathrm{Ca}^{2+}\right]_{\mathrm{i}}$ responses to stimulation with a cold ramp (from $37^{\circ} \mathrm{C}$ to $12^{\circ} \mathrm{C}$ ). The traces in $\boldsymbol{A}$ and $\boldsymbol{B}$ are average responses in groups of cells $(n=25-50$ cells). $\boldsymbol{C}$, Average peak amplitude from experiments like those in $\boldsymbol{A}, \boldsymbol{B}$, and Figure $3 A$ [the arachidonic acid (AA) data are the same as those shown in Fig. 3D].

Table $3 . \mathrm{IC}_{50}$ values for polyunsaturated fatty acids as inhibitors of icilin and menthol

\begin{tabular}{lll}
\hline & \multicolumn{1}{|c}{$\mathrm{IC}_{50}(\mu \mathrm{M})$} & \\
\cline { 2 - 3 } Inhibitor & $\mathrm{I}$ cilin $(1 \mu \mathrm{M})$ & Menthol $(50 \mu \mathrm{M})$ \\
\hline AA (20:4) & $1.3 \pm 0.1$ & $3.2 \pm 0.6$ \\
EPA (20:5) & $2.4 \pm 0.1$ & $6.3 \pm 0.9$ \\
DOHA (22:6) & $1.6 \pm 0.2$ & $2.0 \pm 0.3$ \\
\hline
\end{tabular}

All values are mean \pm SEM of $n=3-5$ experiments.

\section{TRPM8 is inhibited by polyunsaturated} fatty acids

All PLA 2 enzymes hydrolyze the sn-2 ester of glycerophospholipids to release a free fatty acid and a LPL. Arachidonic acid and endogenous metabolites of arachidonate are known activators of other thermosensitive TRP channels: TRPV1, TRPV3, TRPV4, and TRPA1 (Zygmunt et al., 1999; Hwang et al., 2000; Watanabe et al., 2003; Bandell et al., 2004; Hu et al., 2006). TRPM2, the ion channel with greatest homology to TRPM8, can also be activated by arachidonic acid (Hara et al., 2002; Togashi et al., 2006). We therefore examined the potential regulatory role of arachidonic acid and related fatty acids on TRPM8.

Unlike the findings with other thermosensitive TRP channels, arachidonic acid reduced the cold, icilin, and menthol sensitivity of CHO cells expressing TRPM8. Arachidonic acid (10 $\mu \mathrm{M})$ depressed the $\left[\mathrm{Ca}^{2+}\right]_{\mathrm{i}}$ responses to icilin $(1 \mu \mathrm{M})$ by $97 \pm 1 \%$ and to cold stimulation (measured at $13^{\circ} \mathrm{C}$ ) by $96 \pm 2 \%$. A smaller $(76 \pm 2 \%)$, but highly significant, inhibition of the reexperiments indicated.
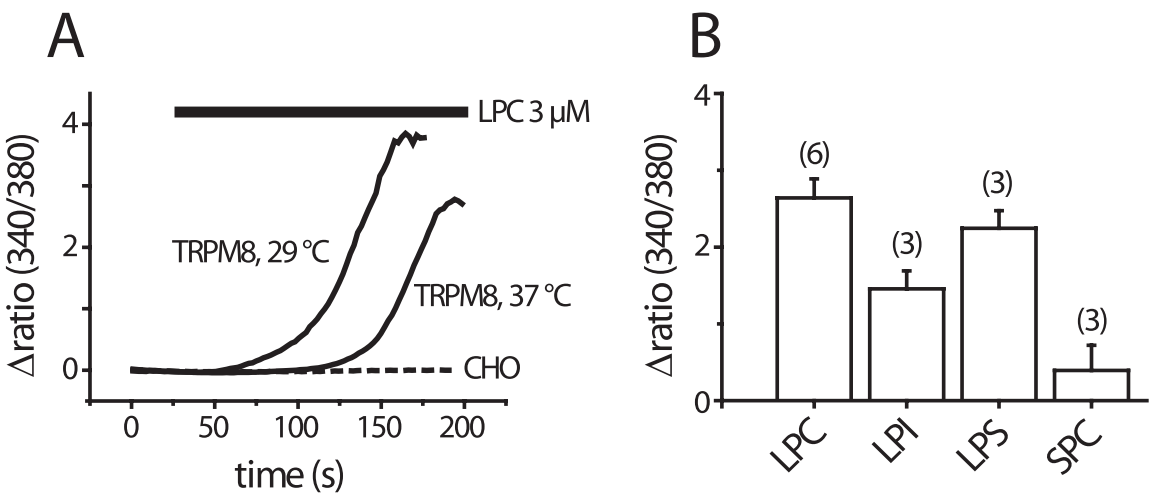

Figure 5. TRPM8 is activated by lysophospholipids. $A$, Lysophosphatidylcholine elicited $\left[\mathrm{Ca}^{2+}\right]_{\mathrm{i}}$ responses in cells expressing TRPM8 but not in untransfected CHO cells. After a longer initial delay, LPC also activated TRPM8 at $37^{\circ} \mathrm{C}$ (traces are averages of 25-40 cells monitored individually). B, TRPM8 was activated by lysophospholipids with different head groups. The negatively charged $L P I$ and $L P S$ evoked $\left[\mathrm{Ca}^{2+}\right]_{\mathrm{i}}$ responses of amplitude similar to the zwitterionic $L P C$, whereas SPC was much less effective (all at a concentration of $3 \mu \mathrm{M}$ ). Experiments were performed at $29^{\circ} \mathrm{C}$, and the data in $\boldsymbol{B}$ are mean \pm SEM of the number of

sponse to $100 \mu \mathrm{M}$ menthol was recorded in the presence of arachidonic acid (Fig. 3). To discern whether the observed inhibition was specific for arachidonic acid (20:4) or a more general property of polyunsaturated fatty acids, we also tested the effects 
A

Menthol $50 \mu \mathrm{M}$

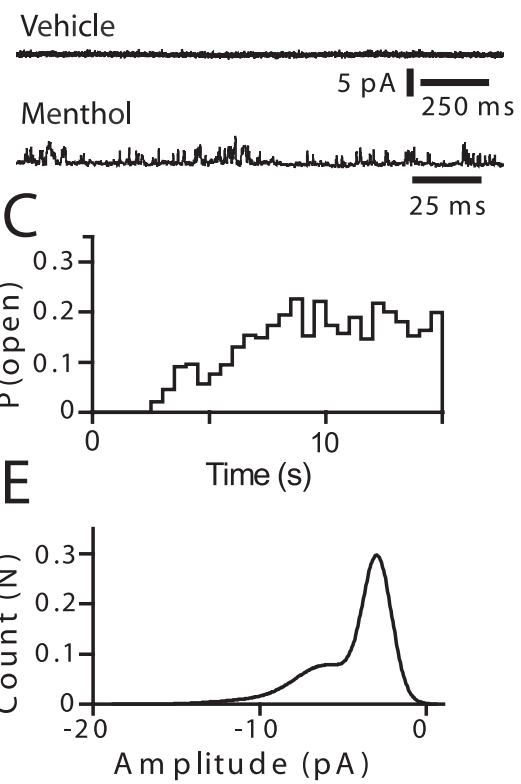

G

Cell-attached, Veh

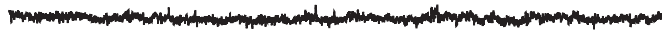

Cell-attached, LPC $3 \mu \mathrm{M}$

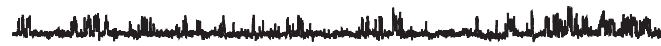

Inside out, LPC $3 \mu \mathrm{M}$

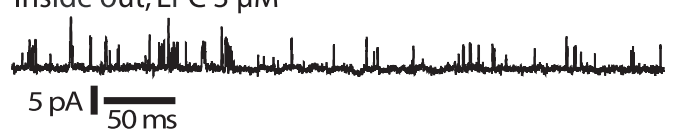

LPC $3 \mu \mathrm{M}$
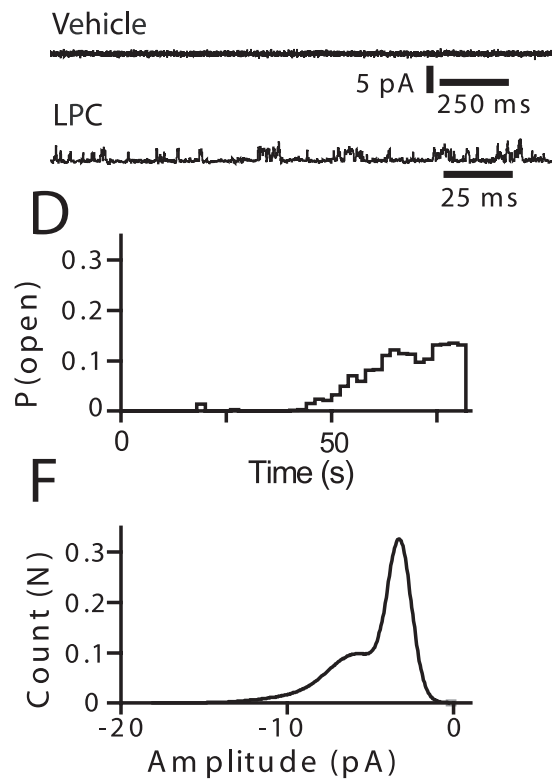

inhibition of $\mathrm{iPLA}_{2}$ as well as treatment with arachidonic acid prevented activation of TRPM8, we next tested whether LPLs could act as endogenous activators or positive modulators of TRPM8 (Fig. $5)$.

Application of $3 \mu \mathrm{M}$ lysophosphatidylcholine (LPC) (16:0) produced large $\left[\mathrm{Ca}^{2+}\right]_{\mathrm{i}}$ responses in $\mathrm{CHO}$ cells transfected with TRPM8 ( $\Delta$ ratio $2.6 \pm 0.2$ ) but not in untransfected control cells $(\Delta$ ratio $0.1 \pm 0.1)$. LPC $(3 \mu \mathrm{M})$ was able to induce $\left[\mathrm{Ca}^{2+}\right]_{\mathrm{i}}$ responses in TRPM8 at $37^{\circ} \mathrm{C}$ although with a longer delay than at $29^{\circ} \mathrm{C}$ (Fig. $5 \mathrm{~A}$ ). $\mathrm{PLA}_{2}$ activity in vivo is likely to produce a mixture of LPLs with different head groups and acyl chains. To explore whether LPLs containing head groups with different properties can activate TRPM8, we used the anionic lysophosphatidylinositol (LPI) and lysophosphatidylserine (LPS) as well as the zwitterionic LPC. We also tested the effects of a sphingolipid, sphingosyl-phosphorylcholine (SPC). The $\left[\mathrm{Ca}^{2+}\right]_{\mathrm{i}}$ responses evoked by $3 \mu \mathrm{M}$ LPI and LPS were similar to those elicited by LPC, whereas SPC was much less effective at this concentration (Fig. $5 B)$. We were unable to construct full agonist concentration-response curves for the lysophospholipids acting at TRPM8 because higher concentrations $(\geq 5 \mu \mathrm{M})$ evoked a second type of cellular $\left[\mathrm{Ca}^{2+}\right]_{\mathrm{i}}$ response that was evident in untransfected $\mathrm{CHO}$ cells (data not shown). Nevertheless, we noted that lower ( 1 and $2 \mu \mathrm{M})$ concentrations of LPC, LPI, and LPS produced mean $\left[\mathrm{Ca}^{2+}\right]_{\mathrm{i}}$ responses that showed little difference in amplitude between the lipid species (data not shown). We investigated the importance of the fatty acid chain length for LPL activity by examining the effects of an LPC with a much shorter acyl chain (6:0). This short-chain LPC failed to activate TRPM8 even at con-

of $10 \mu \mathrm{M}$ eicosapentaenoic acid (20:5) and docosahexaenoic acid (22:6) on the cold responses of TRPM8. The results shown in Figure 4 clearly demonstrate that cold activation of TRPM8 was almost completely inhibited by all three polyunsaturated fatty acids. This was also the case with $\left[\mathrm{Ca}^{2+}\right]_{\mathrm{i}}$ responses induced by menthol $(50 \mu \mathrm{M})$ and icilin $(1 \mu \mathrm{M}) . \mathrm{IC}_{50}$ values determined from concentration-response curves showed that all three fatty acids inhibit responses to icilin and menthol with similar potencies (Table 3 ). The results suggest that TRPM8 can be regulated by variations in the cellular concentrations of PUFAs.

\section{Lysophosphospholipids stimulate TRPM8}

$\mathrm{PLA}_{2}$ liberates LPLs as well as fatty acids, and $\mathrm{iPLA}_{2}$ has been suggested to regulate store-operated calcium entry through production of LPLs (Smani et al., 2004). Because we discovered that centrations as high as $40 \mu \mathrm{M}$ (data not shown)

To further demonstrate that LPC can activate TRPM8, we compared the single-channel activity evoked by menthol and LPC in cell-attached membrane patches (Fig. 6). Before application of menthol or LPC, no channel activity was recorded in the patches. Application of menthol $(50 \mu \mathrm{M})$ to the cells elicited brief channel openings within a few seconds with a mean singlechannel current amplitude of $2.9 \pm 0.1 \mathrm{pA}$ at $+60 \mathrm{mV}$. LPC (3 $\mu \mathrm{M})$ evoked channel activity similar to menthol (single-channel current amplitude $3.1 \pm 0.1 \mathrm{pA}$ at $+60 \mathrm{mV}$ ) but after a much longer delay (Fig. 6C,D). This delay may reflect slow penetration of the cell membrane attributable to the amphiphathic character of LPC. In a different set of experiments, LPC ( $3 \mu \mathrm{M})$ was applied in cell-attached mode, and when channel activity had developed, we excised the membrane patch in the continued presence of LPC 
to record channel activity in the inside-out patch configuration (Fig. 6G). After excision, $\mathrm{P}$ (open) decreased as reported previously (Reid and Flonta, 2002; Voets et al., 2004), but there was still marked channel activity in the patch, suggesting that LPC is able to activate TRPM8 in a membranedelimited manner.

Menthol potentiates the effect of cooling on TRPM8 by raising the temperature threshold (Reid and Flonta, 2001; McKemy et al., 2002; Peier et al., 2002a). We found that this was also the case with LPC. LPC strongly potentiated the whole-cell currents and $\left[\mathrm{Ca}^{2+}\right]_{\mathrm{i}}$ responses evoked by cooling. In electrophysiology experiments, the threshold for temperature activation in the presence of $3 \mu \mathrm{M}$ LPC was raised by $3-5^{\circ} \mathrm{C}$ and the amplitude of the cold-evoked current at $11^{\circ} \mathrm{C}$ was increased sixfold from $190 \pm 90$ to $1280 \pm 190 \mathrm{pA}$ (Fig. 7A). The effect of LPC on $\left[\mathrm{Ca}^{2+}\right]_{\mathrm{i}}$ responses elicited by cooling was much more dramatic. Application of increasing concentrations of LPC (1-3 $\mu \mathrm{M})$ progressively elevated the temperature activation threshold. At $3 \mu \mathrm{M}$, TRPM8 was activated at $37^{\circ} \mathrm{C}$ in many cells. The augmented cold-activated $\left[\mathrm{Ca}^{2+}\right]_{\mathrm{i}}$ responses in the presence of LPC were caused by a calcium influx through TRPM8 because it was dependent on the presence of extracellular $\mathrm{Ca}^{2+}$ (Fig. 7B). In addition, LPC had no effect on $\left[\mathrm{Ca}^{2+}\right]_{\mathrm{i}}$ in untransfected $\mathrm{CHO}$ cells (data not shown).

If $\mathrm{PLA}_{2}$ is important for TRPM8 activation because it produces LPLs, TRPM8 activation by LPLs should be resistant to $\mathrm{PLA}_{2}$ inhibitors. We tested this by applying LPC to cells incubated with $10 \mu \mathrm{M}$ ACA, a concentration that inhibits responses to menthol, icilin, and cold (Figs. 1, 2). As predicted, ACA failed to affect responses to LPC (Fig. 8A). TRPM8 activation by cold and icilin, but not menthol, is inhibited by reducing the external and internal $\mathrm{pH}$ (Andersson et al., 2004). LPC shared this feature because application of LPC ( $3 \mu \mathrm{M})$ failed to evoke any responses in an external solution of pH 6 (Fig. 8A).

One apparent paradox is that two products of $\mathrm{iPLA}_{2}$ activity, LPLs and PUFAs, have opposite actions on TRPM8. To address this balance between the excitatory and inhibitory effects of LPLs and PUFAs, we applied equimolar concentrations $(3 \mu \mathrm{M})$ of arachidonic acid and LPC to TRPM8-expressing cells at $31^{\circ} \mathrm{C}$. Under these conditions, the amplitude of $\left[\mathrm{Ca}^{2+}\right]_{\mathrm{i}}$ responses induced by LPC were only marginally reduced by the presence of arachidonic acid (Fig. $8 \mathrm{~B}$ ). However, a higher concentration of arachidonic acid $(10 \mu \mathrm{M})$ was able to inhibit activation of TRPM8 by $3 \mu \mathrm{M}$ LPC (Fig. 8C).

B
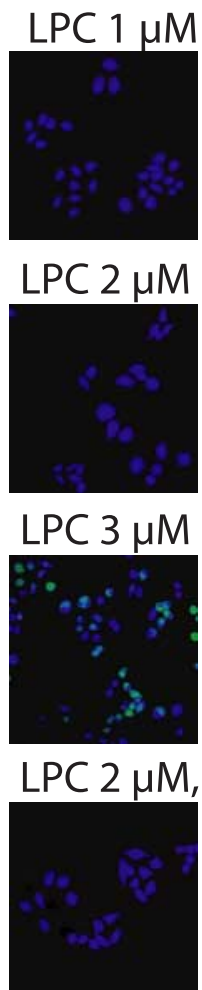
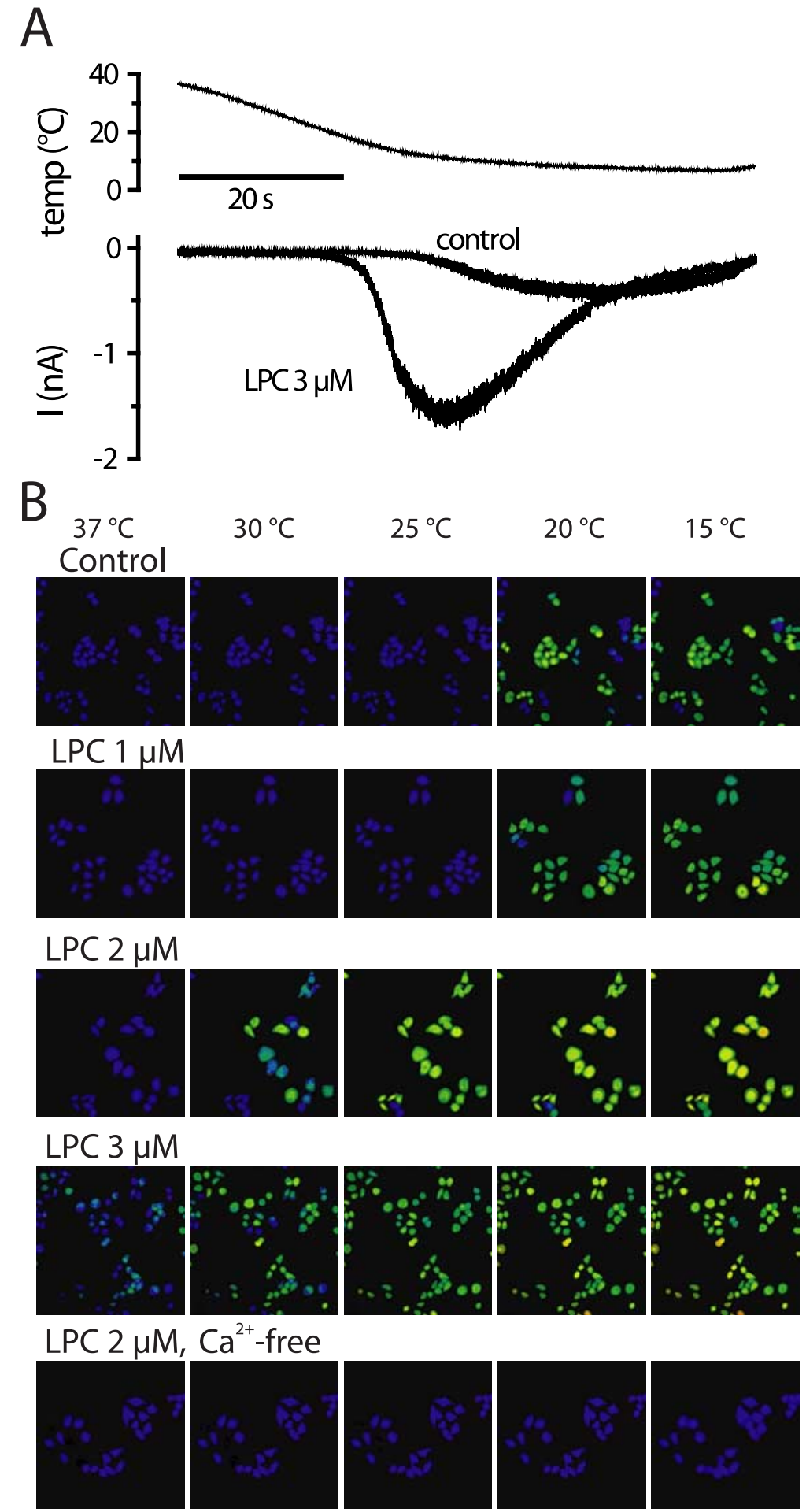

$\mathrm{R}_{340 / 380}$

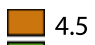

3

1.5

Figure 7. LPC modulates the cold sensitivity of TRPM8.A, LPC potentiates responses to cold by increasing the current amplitude and by shifting the activation threshold to higher temperatures (temp). $\boldsymbol{B}$, Pseudocolored ratio images from $\left[\mathrm{Ca}^{2+}\right]_{\mathrm{i}}$ imaging experiments illustrating that $L P C$ shifts the temperature activation threshold of TRPM8 closer to physiologically relevant values. № response was seen in the absence of extracellular $\mathrm{Ca}^{2+}$.

\section{Discussion}

Our results have demonstrated a key role for $\mathrm{PLAA}_{2}$ in modulating TRPM8 activity. Furthermore, we have demonstrated that the products of PLA 2 , LPLs and PUFAs, can modulate TRPM8 activity in a reciprocal manner. Lysophospholipids act as positive modulators, whereas PUFAs inhibit TRPM8 activity. Our findings are consistent with a very recent study demonstrating that 

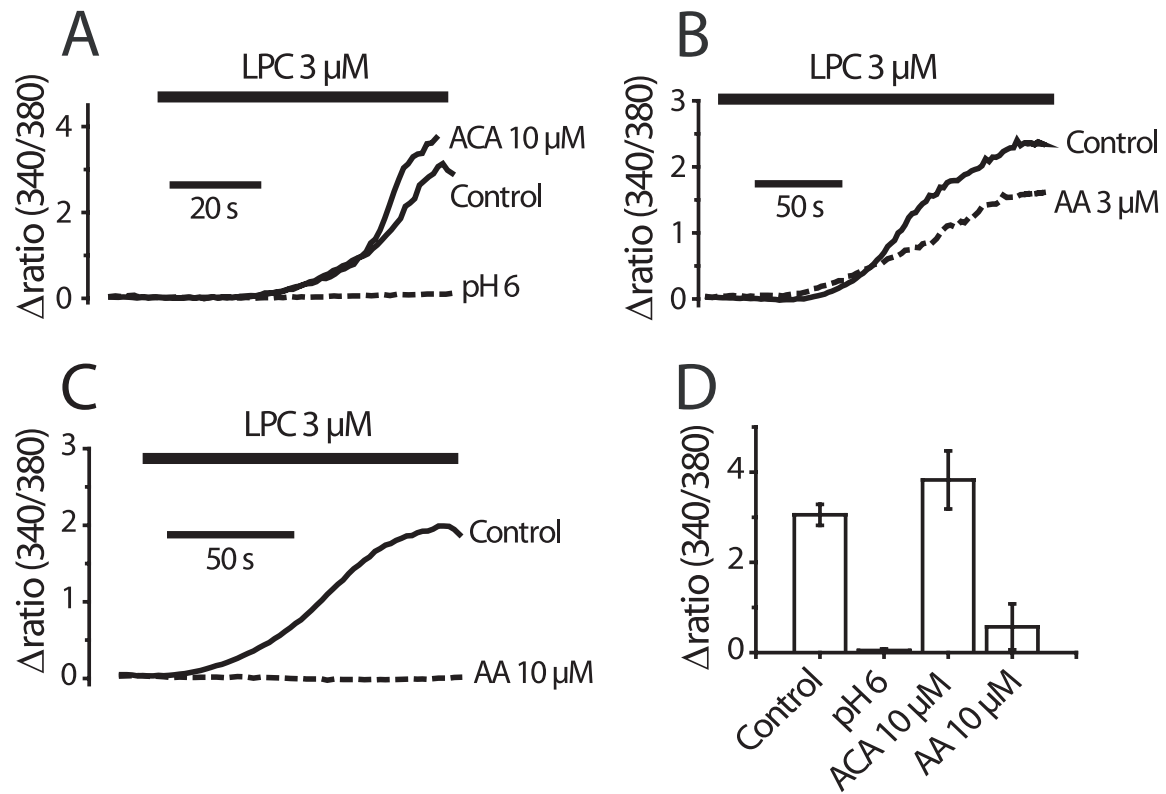

Figure 8. $L P C$ is resistant to inhibition of $P L A_{2}$ but sensitive to low $\mathrm{pH}$. $\boldsymbol{A}$, The agonist effect of $\mathrm{LPC}(3 \mu \mathrm{m})$ on TRPM8 is unaffected by the presence of $10 \mu \mathrm{m}$ ACA. Cells incubated in pH 6 for 1 min before stimulation failed to respond to LPC. $\boldsymbol{B}$, Application of equimolar concentrations of LPC and arachidonic acid (AA) only produced a small reduction of the LPC induced $\left[\mathrm{Ca}^{2+}\right]_{\mathrm{i}}$ responses. C, However, $10 \mu \mathrm{m}$ arachidonic acid completely inhibited the response to $3 \mu \mathrm{M} \mathrm{LPC.} \mathrm{D,} \mathrm{Average} \mathrm{of} \mathrm{the} \mathrm{peak}$ amplitude in three determinations in groups of $20-40$ cells.

iPLA $_{2}$ inhibition partially reduced menthol sensitivity (Abeele et al., 2006). These authors also showed that LPC and LPI could activate TRPM8 expressed in human embryonic kidney 293 cells.

Addition of LPLs raised the thermal threshold for activation so that TRPM 8 could be activated by $3 \mu \mathrm{M} \mathrm{LPC}$ at $37^{\circ} \mathrm{C}$. LPC had a more dramatic effect on temperature sensitivity in experiments monitoring $\left[\mathrm{Ca}^{2+}\right]_{i}$ than in voltage-clamp experiments. The reason for this difference is unclear, but it may reflect a loss of a regulatory factor when the intracellular contents are dialysed by the pipette solution in the whole-cell configuration. LPLs acted relatively slowly over many tens of seconds, which suggests that the site of action was intracellular and that activation required translocation across the plasma membrane. The speed of action of LPLs on TRPM8 differs from the almost immediate effects of LPLs on TWIK-related $\mathrm{K}+$ channels (TREK) in which the site of action is thought to be extracellular (Maingret et al., 2000). Because $\mathrm{iPLA}_{2}$ is an intracellular enzyme, the supply of endogenous LPLs to the inner surface of the plasma membrane and subsequent modulation of TRPM8 is likely to be a faster process than suggested by the slow responses to extracellular LPLs observed in our studies.

LPLs are known to modulate the activities of other membrane channels including TREK-1 (Lesage et al., 2000; Maingret et al., 2000) and TRPC5 (Flemming et al., 2006) and can regulate storeoperated calcium entry (Smani et al., 2004; Singaravelu et al., 2006). TRPC5 activation by LPLs is also relatively slow and probably requires translocation of the LPL to the internal membrane surface. The absence of LPL responses in untransfected cells at the concentrations studied and the similar properties of LPC- and menthol-activated single-channel currents indicate that the responses to LPLs are mediated by TRPM8 and not by a nonspecific action on membrane lipids (cf. Wilson-Ashworth et al., 2004). How LPLs regulate TRPM8 is unclear. The observation that LPC evoked single-channel current activity was retained when membrane patches were excised into the inside-out configuration sug- gests that LPLs act on TRPM8 in a membrane-delimited manner. They could have an indirect effect on channel function by interacting with either plasma membrane lipids or channel-associated proteins or a direct effect by binding to TRPM8. We did note that there was no significant difference in the activity of the anionic LPI (16:0) and the zwitterionic LPC (16:0). However, a short-chain species of LPC (6:0) lacked activity altogether, whereas the sphingolipid SPC (16:0) was less active than LPI and LPC. These results suggest that both the length of the fatty acyl chain and the properties of the headgroup influence their actions at TRPM8.

Arachidonic acid and two other PUFAs (docosahexaenoic acid and eicosapentaenoic acid) inhibited TRPM8 with approximately equal potency. This inhibition contrasts with the activation of other thermosensitive TRP channels by PUFAs and arachidonic acid metabolites. Once again it is unclear whether the inhibitory effect of the PUFAs is mediated by an interaction with the plasma membrane or TRPM8 itself.

Continued PLA $_{2}$ activity was essential for the maintenance of cold and icilin sensitivity and the ability of these stimuli to activate TRPM8 was lost within minutes of adding the enzyme inhibitors. $\mathrm{iPLA}_{2}$ is considered to have a housekeeping role in cells regulating the turnover of membrane lipids (Balsinde and Balboa, 2005). Consequently, the concentration of LPLs will decrease when PLA $_{2}$ is inhibited as the existing LPLs continue to be acylated by acyltransferases. The loss of cold and icilin sensitivity a few minutes after adding PLA $_{2}$ inhibitors is therefore consistent with a tonic regulatory role for LPLs generated by $\mathrm{PLA}_{2}$.

The pharmacology of icilin and cold differs from that of menthol with respect to $\mathrm{pH}_{\mathrm{i}}$ sensitivity, dependence on extracellular $\mathrm{Ca}^{2+}$, and iPLA 2 activity (Andersson et al., 2004; Chuang et al., 2004) (Fig. 2). LPC shared the $\mathrm{pH}$ sensitivity with cold and icilin, suggesting that there is a common step or cofactor requirement for cold, icilin, and LPL activation that is not shared by menthol. Importantly, the action of LPC was resistant to a high concentration of ACA.

LPLs and PUFAs are both released by PLA $_{2}$, which raised the possibility that the stimulatory effect of LPLs might be cancelled out by the coincident inhibitory action of the PUFAs. However, this scenario is unlikely. First, the reduction in icilin and cold sensitivity after iPLA $_{2}$ inhibition is consistent with an overall stimulatory effect of the $\mathrm{PLA}_{2}$ products. Second, when we applied LPC and arachidonic acid at equimolar concentrations, LPC still evoked large $\left[\mathrm{Ca}^{2+}\right]_{\mathrm{i}}$ responses. Third, $\mathrm{PPLA}_{2}$ lacks substrate specificity for phospholipids containing particular fatty acids in sn-2 position (unlike $\mathrm{CPLA}_{2}$, which is selective for arachidonic acid) and therefore releases a mixture of saturated and unsaturated fatty acids (Balsinde and Balboa, 2005).

The ability of LPLs to act as positive modulators of TRPM8 function raises the possibility that treatments that increase their concentration will alter the thermal threshold for activation and may even open the channels at normal body temperature $\left(37^{\circ} \mathrm{C}\right)$. There is growing evidence that $\mathrm{PLA}_{2}$ is involved in some cell 
signaling pathways in addition to its role in homeostatic phospholipid deacylation/reacylation reactions (Smani et al., 2004; Balsinde and Balboa, 2005; Singaravelu et al., 2006). The other major intracellular $\mathrm{PLA}_{2}$ enzyme, $\mathrm{CPLA}_{2}$, is activated by micromolar levels of intracellular calcium and plays a central role in lipid mediator production in pathological conditions, including inflammation, primarily through the release of arachidonic acid and its metabolites (Kita et al., 2006). Although our data indicate that $\mathrm{CPLA}_{2}$ does not have a role in maintaining basal TRPM8 activity, stimuli that stimulate $\mathrm{CPLA}_{2}$ to generate LPLs could sensitize or activate TRPM8.

The phospholipid $\mathrm{PIP}_{2}$ can control the activity and desensitization of TRPM8, and a reduction in the $\mathrm{PIP}_{2}$ levels has been shown previously to explain the rundown of TRPM8 channels in isolated patches (Fig. 6) (Liu and Qin, 2005; Rohacs et al., 2005). This channel rundown and associated decrease in $\mathrm{PIP}_{2}$ concentrations is dramatically accelerated in the presence of $\mathrm{Mg}^{2+}$ (Huang et al., 1998; Liu and Qin, 2005). Because LPC (3 $\mu \mathrm{M})$ evoked channel activity was maintained in excised patches in the presence of $\mathrm{Mg}^{2+}$ ( $1 \mathrm{~mm}$ in all recording solutions), $\mathrm{PIP}_{2}$ does not seem to be required for the actions of LPLs on TRPM8.

TRPM8 is a physiological sensor of cold and cool temperatures (McKemy et al., 2002; Peier et al., 2002a). However, temperature alone is unlikely to account for activation of TRPM8 in all tissues because this channel is expressed in sensory nerves innervating visceral organs such as the bladder (Mukerji et al., 2006) and lower gastrointestinal tract (Zhang et al., 2004). TRPM8 is also expressed in non-neuronal cells in prostate and bladder (Tsavaler et al., 2001; Stein et al., 2004). These neurons and non-neuronal cells rarely, if ever, experience the low temperatures generally considered to activate TRPM $8\left(<25^{\circ} \mathrm{C}\right)$. In these cells, endogenous modulators, such as LPLs and $\mathrm{PIP}_{2}$, would raise the temperature threshold so that TRPM8 can operate at physiological body temperatures. These lipid modulators could therefore have two roles: setting the temperature sensitivity of cold receptors in the skin and other tissues that are exposed to the external environment and regulating the activity of TRPM8expressing neurons that innervate deeper tissues and organs.

\section{References}

Abeele FV, Zholos A, Bidaux G, Shuba Y, Thebault S, Beck B, Flourakis M, Panchin Y, Skryma R, Prevarskaya N (2006) Ca(2+)-independent phospholipase A(2)-dependent gating of TRPM8 by lysophospholipids. J Biol Chem 281:40174-40182.

Andersson DA, Chase HW, Bevan S (2004) TRPM8 activation by menthol, icilin, and cold is differentially modulated by intracellular $\mathrm{pH}$. J Neurosci 24:5364-5369.

Babes A, Zorzon D, Reid G (2004) Two populations of cold-sensitive neurons in rat dorsal root ganglia and their modulation by nerve growth factor. Eur J Neurosci 20:2276-2282.

Balsinde J, Balboa MA (2005) Cellular regulation and proposed biological functions of group VIA calcium-independent phospholipase A2 in activated cells. Cell Signal 17:1052-1062.

Bandell M, Story GM, Hwang SW, Viswanath V, Eid SR, Petrus MJ, Earley TJ, Patapoutian A (2004) Noxious cold ion channel TRPA1 is activated by pungent compounds and bradykinin. Neuron 41:849-857.

Bevan S, Winter J (1995) Nerve growth factor (NGF) differentially regulates the chemosensitivity of adult rat cultured sensory neurons. J Neurosci 15:4918-4926.

Caterina MJ, Schumacher MA, Tominaga M, Rosen TA, Levine JD, Julius D (1997) The capsaicin receptor: a heat-activated ion channel in the pain pathway. Nature 389:816-824.

Caterina MJ, Rosen TA, Tominaga M, Brake AJ, Julius D (1999) A capsaicin-receptor homologue with a high threshold for noxious heat. Nature 398:436-441.

Chuang HH, Neuhausser WM, Julius D (2004) The super-cooling agent icilin reveals a mechanism of coincidence detection by a temperaturesensitive TRP channel. Neuron 43:859-869.

Clapham DE (2003) TRP channels as cellular sensors. Nature 426:517-524. Flemming PK, Dedman AM, Xu SZ, Li J, Zeng F, Naylor J, Benham CD, Bateson AN, Muraki K, Beech DJ (2006) Sensing of lysophospholipids by TRPC5 calcium channel. J Biol Chem 281:4977-4982.

Fuentes L, Perez R, Nieto ML, Balsinde J, Balboa MA (2003) Bromoenol lactone promotes cell death by a mechanism involving phosphatidate phosphohydrolase-1 rather than calcium-independent phospholipase A2. J Biol Chem 278:44683-44690.

Guler AD, Lee H, Iida T, Shimizu I, Tominaga M, Caterina M (2002) Heatevoked activation of the ion channel, TRPV4. J Neurosci 22:6408-6414.

Hara Y, Wakamori M, Ishii M, Maeno E, Nishida M, Yoshida T, Yamada H, Shimizu S, Mori E, Kudoh J, Shimizu N, Kurose H, Okada Y, Imoto K, Mori Y (2002) LTRPC2 Ca2+-permeable channel activated by changes in redox status confers susceptibility to cell death. Mol Cell 9:163-173.

Hardie RC (2003) Regulation of TRP channels via lipid second messengers. Annu Rev Physiol 65:735-759.

Hu HZ, Xiao R, Wang C, Gao N, Colton CK, Wood JD, Zhu MX (2006) Potentiation of TRPV3 channel function by unsaturated fatty acids. J Cell Physiol 208:201-212.

Huang CL, Feng S, Hilgemann DW (1998) Direct activation of inward rectifier potassium channels by PIP2 and its stabilization by Gbetagamma. Nature 391:803-806.

Hwang SW, Cho H, Kwak J, Lee SY, Kang CJ, Jung J, Cho S, Min KH, Suh YG, Kim D, Oh U (2000) Direct activation of capsaicin receptors by products of lipoxygenases: endogenous capsaicin-like substances. Proc Natl Acad Sci USA 97:6155-6160.

Jordt SE, McKemy DD, Julius D (2003) Lessons from peppers and peppermint: the molecular logic of thermosensation. Curr Opin Neurobiol 13:487-492.

Kita Y, Ohto T, Uozumi N, Shimizu T (2006) Biochemical properties and pathophysiological roles of cytosolic phospholipase A(2)s. Biochim Biophys Acta 1761:1317-1322.

Lanni C, Becker EL (1985) Inhibition of neutrophil phospholipase A2 by p-bromophenylacyl bromide, nordihydroguaiaretic acid, 5,8,11,14eicosatetraynoic acid and quercetin. Int Arch Allergy Appl Immunol $76: 214-217$.

Lesage F, Terrenoire C, Romey G, Lazdunski M (2000) Human TREK2, a 2P domain mechano-sensitive $\mathrm{K}+$ channel with multiple regulations by polyunsaturated fatty acids, lysophospholipids, and Gs, Gi, and Gq protein-coupled receptors. J Biol Chem 275:28398-28405.

Liu B, Qin F (2005) Functional control of cold- and menthol-sensitive TRPM8 ion channels by phosphatidylinositol 4,5-bisphosphate. J Neurosci $25: 1674-1681$.

Liu D, Liman ER (2003) Intracellular Ca2 + and the phospholipid PIP2 regulate the taste transduction ion channel TRPM5. Proc Natl Acad Sci USA 100:15160-15165.

Maingret F, Patel AJ, Lesage F, Lazdunski M, Honore E (2000) Lysophospholipids open the two-pore domain mechano-gated $\mathrm{K}(+)$ channels TREK-1 and TRAAK. J Biol Chem 275:10128-10133.

McKemy DD, Neuhausser WM, Julius D (2002) Identification of a cold receptor reveals a general role for TRP channels in thermosensation. $\mathrm{Na}-$ ture 416:52-58.

Mukerji G, Yiangou Y, Corcoran SL, Selmer IS, Smith GD, Benham CD, Bountra C, Agarwal SK, Anand P (2006) Cool and menthol receptor TRPM8 in human urinary bladder disorders and clinical correlations. BMC Urol 6:6.

Patapoutian A, Peier AM, Story GM, Viswanath V (2003) ThermoTRP channels and beyond: mechanisms of temperature sensation. Nat Rev Neurosci 4:529-539.

Peier AM, Moqrich A, Hergarden AC, Reeve AJ, Andersson DA, Story GM, Earley TJ, Dragoni I, McIntyre P, Bevan S, Patapoutian A (2002a) A TRP channel that senses cold stimuli and menthol. Cell 108:705-715.

Peier AM, Reeve AJ, Andersson DA, Moqrich A, Earley TJ, Hergarden AC, Story GM, Colley S, Hogenesch JB, McIntyre P, Bevan S, Patapoutian A (2002b) A heat-sensitive TRP channel expressed in keratinocytes. Science 296:2046-2049.

Reid G, Flonta ML (2001) Physiology. Cold current in thermoreceptive neurons. Nature 413:480.

Reid G, Flonta ML (2002) Ion channels activated by cold and menthol in cultured rat dorsal root ganglion neurones. Neurosci Lett 324:164-168. 
Rohacs T, Lopes CM, Michailidis I, Logothetis DE (2005) PI(4,5)P(2) regulates the activation and desensitization of TRPM8 channels through the TRP domain. Nat Neurosci 8:626-634.

Runnels LW, Yue L, Clapham DE (2002) The TRPM7 channel is inactivated by PIP(2) hydrolysis. Nat Cell Biol 4:329-336.

Seno K, Okuno T, Nishi K, Murakami Y, Yamada K, Nakamoto S, Ono T (2000) Pyrrolidine inhibitors of human cytosolic phospholipase A(2). J Med Chem 43:1041-1044.

Singaravelu K, Lohr C, Deitmer JW (2006) Regulation of store-operated calcium entry by calcium-independent phospholipase A2 in rat cerebellar astrocytes. J Neurosci 26:9579-9592.

Smani T, Zakharov SI, Csutora P, Leno E, Trepakova ES, Bolotina VM (2004) A novel mechanism for the store-operated calcium influx pathway. Nat Cell Biol 6:113-120.

Smith GD, Gunthorpe MJ, Kelsell RE, Hayes PD, Reilly P, Facer P, Wright JE, Jerman JC, Walhin JP, Ooi L, Egerton J, Charles KJ, Smart D, Randall AD, Anand P, Davis JB (2002) TRPV3 is a temperature-sensitive vanilloid receptor-like protein. Nature 418:186-190.

Stein RJ, Santos S, Nagatomi J, Hayashi Y, Minnery BS, Xavier M, Patel AS, Nelson JB, Futrell WJ, Yoshimura N, Chancellor MB, De Miguel F (2004) Cool (TRPM8) and hot (TRPV1) receptors in the bladder and male genital tract. J Urol 172:1175-1178.

Story GM, Peier AM, Reeve AJ, Eid SR, Mosbacher J, Hricik TR, Earley TJ, Hergarden AC, Andersson DA, Hwang SW, McIntyre P, Jegla T, Bevan S, Patapoutian A (2003) ANKTM1, a TRP-like Channel Expressed in Nociceptive Neurons, Is Activated by Cold Temperatures. Cell 112:819-829.

Togashi K, Hara Y, Tominaga T, Higashi T, Konishi Y, Mori Y, Tominaga M
(2006) TRPM2 activation by cyclic ADP-ribose at body temperature is involved in insulin secretion. EMBO J 25:1804-1815.

Tsavaler L, Shapero MH, Morkowski S, Laus R (2001) Trp-p8, a novel prostate-specific gene, is up-regulated in prostate cancer and other malignancies and shares high homology with transient receptor potential calcium channel proteins. Cancer Res 61:3760-3769.

Voets T, Droogmans G, Wissenbach U, Janssens A, Flockerzi V, Nilius B (2004) The principle of temperature-dependent gating in cold- and heatsensitive TRP channels. Nature 430:748-754.

Watanabe H, Vriens J, Prenen J, Droogmans G, Voets T, Nilius B (2003) Anandamide and arachidonic acid use epoxyeicosatrienoic acids to activate TRPV4 channels. Nature 424:434-438.

Wilson-Ashworth HA, Judd AM, Law RM, Freestone BD, Taylor S, Mizukawa MK, Cromar KR, Sudweeks S, Bell JD (2004) Formation of transient non-protein calcium pores by lysophospholipids in S49 Lymphoma cells. J Membr Biol 200:25-33.

$\mathrm{Xu}$ H, Ramsey IS, Kotecha SA, Moran MM, Chong JA, Lawson D, Ge P, Lilly J, Silos-Santiago I, Xie Y, DiStefano PS, Curtis R, Clapham DE (2002) TRPV3 is a calcium-permeable temperature-sensitive cation channel. Nature 418:181-186.

Zhang L, Jones S, Brody K, Costa M, Brookes SJ (2004) Thermosensitive transient receptor potential channels in vagal afferent neurons of the mouse. Am J Physiol Gastrointest Liver Physiol 286:G983-G991.

Zygmunt PM, Petersson J, Andersson DA, Chuang H, Sorgard M, Di M, V, Julius D, Hogestatt ED (1999) Vanilloid receptors on sensory nerves mediate the vasodilator action of anandamide. Nature 400:452-457. 